\title{
Visual spatial representation of social and cultural phenomena and its effect on local education: The case of Papua New Guinea
}

\author{
Martin Soukup - Jan D. Bláha
}

DOI: 10.21104/CL.2018.3.03

\begin{abstract}
This study uses participatory research in spatial anthropology.

The aim of the study is to demonstrate the possibilities in using maps in ethnology and anthropology, and to introduce the potential of the interdisciplinary cooperation of cartographers and geographers with ethnologists and anthropologists. In addition, the authors try to demonstrate the influence of maps and visual information on the life of a local community and local education using examples. In their study, the authors show the results of the field research which they carried out together on the Nungon community in Papua New Guinea. The authors show that sharing the results of the research with the participants may generate other research questions and bring new research topics in spatial anthropology.
\end{abstract}

Key words spatial anthropology, mental maps, visuality, Papua New Guinea.

This article was prepared as part of the research project No. 16-01003S “Visual geographical information and its role in geography teaching and learning" supported by the Czech Science Foundation (Jan D. Bláha). This study was written with the support of the Ministry of Education, Youth and Sports, grant project IGA_FF_2018_023 (Social Sciences 2018) (Martin Soukup).

Contact Doc. PhDr. Martin Soukup, Ph.D., Katedra sociologie, andragogiky a kulturní antropologie, Filozofická fakulta Univerzity Palackého, tř. Svobody 686/26, 77900 Olomouc, Czechia; e-mail: martin.soukup@antropolog.cz.

PhDr. RNDr. Jan D. Bláha, Ph.D., Katedra geografie, Př́rodovědecká fakulta Univerzity Jana Evangelisty Purkyně, České mládeže 8, 40096 Ústí nad Labem, Czechia; e-mail: jd@jackdaniel.cz.

Jak citovat / How to cite Soukup, Martin - Bláha, Jan D. (2018). Visual spatial representation of social and cultural phenomena and its effect on local education: The case of Papua New Guinea. Český lid 105: 325-340. doi:http://dx.doi.org/10.21104/CL.2018.3.03 


\section{The study of social and cultural phenomena in space}

Anthropologists have been interested in studying culture and society in regard to geographical space since the very beginning of their science. Some early anthropological paradigms, such as anthropogeography or diffusionism, were explicitly oriented to studying the distribution of cultural and social phenomena in geographical space (an overview within the context of the history of anthropology in Barnard 2000; Kuper 2006; Stocking 1995). This approach was later abandoned in favor of a long-term stationary study of cultures in situ regardless of the spatial attribute.

For geographers, to work with space and spatial representation (mostly maps) is a natural part of their field. However, for quite a long time geography and its methodology were limited by describing natural and social history without any major interconnection. This in some measure historicized the concept of geography without searching for any complex connections between physical and social space, or cultural phenomena, and continued until the beginning of the 20th century (Clifford et al. 2009; Řezníčková 2015). Interestingly, the field of cultural geography began to be established exactly in this period (Sauer 1925) and studied the mutual relationships between physical and cultural geographical space and cultural systems.

Recently anthropologists and geographers reinvented space in relation to globalization (Appadurai 1996; Marcus 1995). There is a diversity in the anthropological and geographical approaches to the study of space and place (Tuan 1977). An overview of anthropology is presented by Low (2003, especially see 2016), of geography in Clifford 2009, Crang 1998, etc. Anthropologists have conducted a large amount of fieldwork focused on the study of how different cultural domains are spatialized, for example, land-tenure in Sri Lanka (Leach 1961); aspects of body and language in Samoa (Durranti 1992); Bourdieau's (2002) the understanding of spatializing gender among Kabyle people; space aspects of the Tirolean economy studied by Pospisil (1995); Evans-Pritchard (1951) attempted spatialized genealogical ties on sketch maps of Nuer villages and camps, etc. We are only citing a few examples; there is extensive literature on space and place in the field of anthropology. On fact, there has been growing interest in space and place in the social sciences and humanities since the 1990s; it is possible to define this interest as "spatial turn" or "spatializing culture" (see e.g. Low 2016; Bodenhamer - Corrigan Harris 2010; Roberts 2018).

The limitation of these research examples is the difficulty in representing the social and cultural phenomena and processes using maps on a small scale. There are some alternative approaches when trying to combine anthropological and geographical tools in order to study the relations between cultural phenomenon and the geographical space (see Dodge - Kitchin - Perkins 2009; Roberts 2012); there has even been an attempt to develop ethnographic 
cartography (Dostal 1984), anthropologists also developed many ethnographic atlases in order to represent cultures in geographical space (for example, Murdock 1967; Price 2004). But there has been no serious attempt to evolve a tested and universally applicable methodological tool for the study of social and cultural phenomena in geographical space. From our perspective, we are more interested in space than place (for approaches to place in anthropology see Okénková 2015). This study focuses on various aspects of space-human relationships in the Uruwa Valley: how do local people sense the space, how do they visualize it and how is it possible to read unwritten past events in geographical space?

\section{Visual spatial information in education}

Various forms of visual information (e.g. mural paintings, smoke signals, primitive sketches and maps, etc.) have been a part of human communication since time immemorial (Kress - van Leeuwen 1990; Ringshausen 1976). However, using visual things for communicating and understanding uncommon and everyday matters also plays an important role in the present. The phenomenon which is referred to as a visual (or iconic) turnover (e.g. Benedek - Nyíri 2012; LaSpina 1998) or simply the coming of visual culture (Dikovitskaya 2005) has contributed greatly to the current expansion of the visual means of communication in various fields of human knowledge and behavior.

Anthropology and geography represent the fields for which visual information is irreplaceable. The importance of visual information can be seen in the fact that visuals offer a more specific and realistic view of phenomena which would otherwise be difficult to grasp. Such examples might also be social and cultural phenomena. Evidently, these phenomena which we deal with on a daily basis (language, family/clan origin, etc.) might be misunderstood or not understood completely without visual representation (Mayer 2001). Moreover, their spatial representation, i.e. a map, offers other valuable information to the community itself; in the case of a map, it is also a key tool for spatial competence development. While people are taught systematically to understand verbal communication during the school teaching process, in the case of visual information its interpretation is not formally taught but instead the skill is expected to automatically develop through experience. But the ability to receive, use and create visual information and products seems to be crucial in everyday life.

\section{The relationship between history and space at a local level}

Our research design cultivates anthropological and cultural-geographical interests in studying the cultural and social phenomena and processes in geographical space. The proposed methodology of the research is designed for 
a local level, which is in contrast to the above-mentioned examples of anthropological and geographical approaches to the globalized world. The principal sources of evidence are the construction of genealogical ties in the Nungon community as well as mapping the Nungon villages (Koteth, Toweth, Yawan). In other words, the research is to be implemented via two principal and mutually linked processes of data construction which provide the main source of evidence. Other sources of evidence are subsidiary to it.

The mental maps were successfully applied to the framework of interdisciplinary designed research that was focused on geographical space and its perception by people (see Downs - Stea 1973). This type of information is helpful for understanding the local perception of space, land attachment, and land ownership perception. Anthropologists are often interested in space, but they obviously study this issue in relation to the environment (Chapin - Lamb - Threlkeld 2005; Pichón 1996); apart from geographers, anthropologists are rarely interested in studying space (territory) in relation to both the history of the community and the perception of the space (however, see Zedeño, 1997).

An important dimension of our research is related to the history of the area and the local people (Soukup - Bláha 2017). There has been growing interest among anthropologists in history since the 1980s. In that decade anthropologists made efforts to re-temporalize anthropology (for example, Fabian 1983; Rosaldo 1980; a current discussion of the issue is included in Rabinow - Marcus - Faubion - Rees 2008). Ever since the 1990s scholars studying this particular area of New Guinea have been predominantly interested in studying the native perception of historical events in the light of archive documents (see Carrier 1990; Schieffelin - Crittenden 1991; Gammage 1998). Many of them study the route of the patrols and how foreigners and locals perceive each other. They mostly ignore geographical space as a stage on which locals face and interpret the events, but these events are simultaneously changing the locals and their worldview and perception of the space. To put it another way, the current state of the area is the result of the historical events partly described in patrol reports, which are interpreted differently by the natives, and by the local social and cultural phenomena.

In contrast to other research, our research focuses on the measurement of geographical space as a basis that serves as a tool to study the local perception of the land and the corresponding human behavior, which are both determined by historical events as well as by the native social and cultural idiom. Additionally, if the space is visually represented in standard and mental maps, we have a very clear and valuable tool at our disposal for communicating with the local community. On the one hand, the community members express their perception of geographical space, or their spatial opinions, by using mental maps, on the other hand, anthropologists and geographers use standard maps to record and present mapped space to the community. 


\section{The case of Papua New Guinea}

Our research focuses on selected communities of the Nungon people. The research is based in the three neighboring villages; a census revealed that there are nearly nine hundred people - Yawan (218), Toweth (386), Koteth (282). Another three rather distant villages are not as important for our research project. The communities from the villages of Mitmit (70), Mup (397) and Worin (196) were excluded. The reason for excluding these communities from the research was to prevent compromising the validity of the study as the members of those villages are not in close everyday contact with the people of Yawan, Toweth and Koteth. The research mainly focuses on the relationships between the people of Yawan, Toweth and Koteth (see fig. 1).

The Nungon people live in the Saruwaged Range in the Morobe Province and their villages are located quite far from the cities. This ethnic group is almost unknown anthropologically. Only a few smaller studies are available, published by the authors as the output of previous fieldwork (see Soukup 2011; Bláha - Soukup - Balcerová 2011; Hubeňáková - Soukup 2012). A general description of Nungon culture was also provided by a missionary, Urs Wegmann (1990), who lived among the Nungons in the 1980s. His study was related to the missionary activities of the Lutheran Church.

The Nungon people were contacted by the Europeans for the first time in the 1920s. The Lutheran missionaries visited that particular area at that time (Wegmann 1990), but they started their missionary activities approximately twenty years later (Village Register 1940). The government authorities began to patrol that part of Uruwa in the mid-thirties, Vial was the first officer who patrolled in the upper Uruwa. Regular patrolling of that particular area started after WWII and continued until the independence of Papua New Guinea. The administrative center for the area was Worin village, which, even for an experienced walker, is a three-hour trek from Yawan.

Archive documents (Village Registers and Patrol reports) suggest that significant events took place in Koteth, Toweth and Yawan at the turn of the forties. The inhabitants of Yawan village were forced to move to a new area to be closer to the administrative center in Worin. A new village was settled on land belonging to land owners from Toweth. There are different interpretations for the motives and responsibility for the forced move. The people of Yawan and Toweth both insist that the patrol officer ordered the people of Yawan to move to the new territory. The entries in the Village Register (1940) suggest a different sequence of events; that the move was ordered by the Lutheran missionary and his mission helpers in order to facilitate the spreading of the gospel in the area. There is an entry containing the patrol officer's disagreement with the move because of health risks concerning the huge population being amalgamated into village. Whatever the reason, this particular issue still affects life in the community and is a subject of discussion on landownership. 


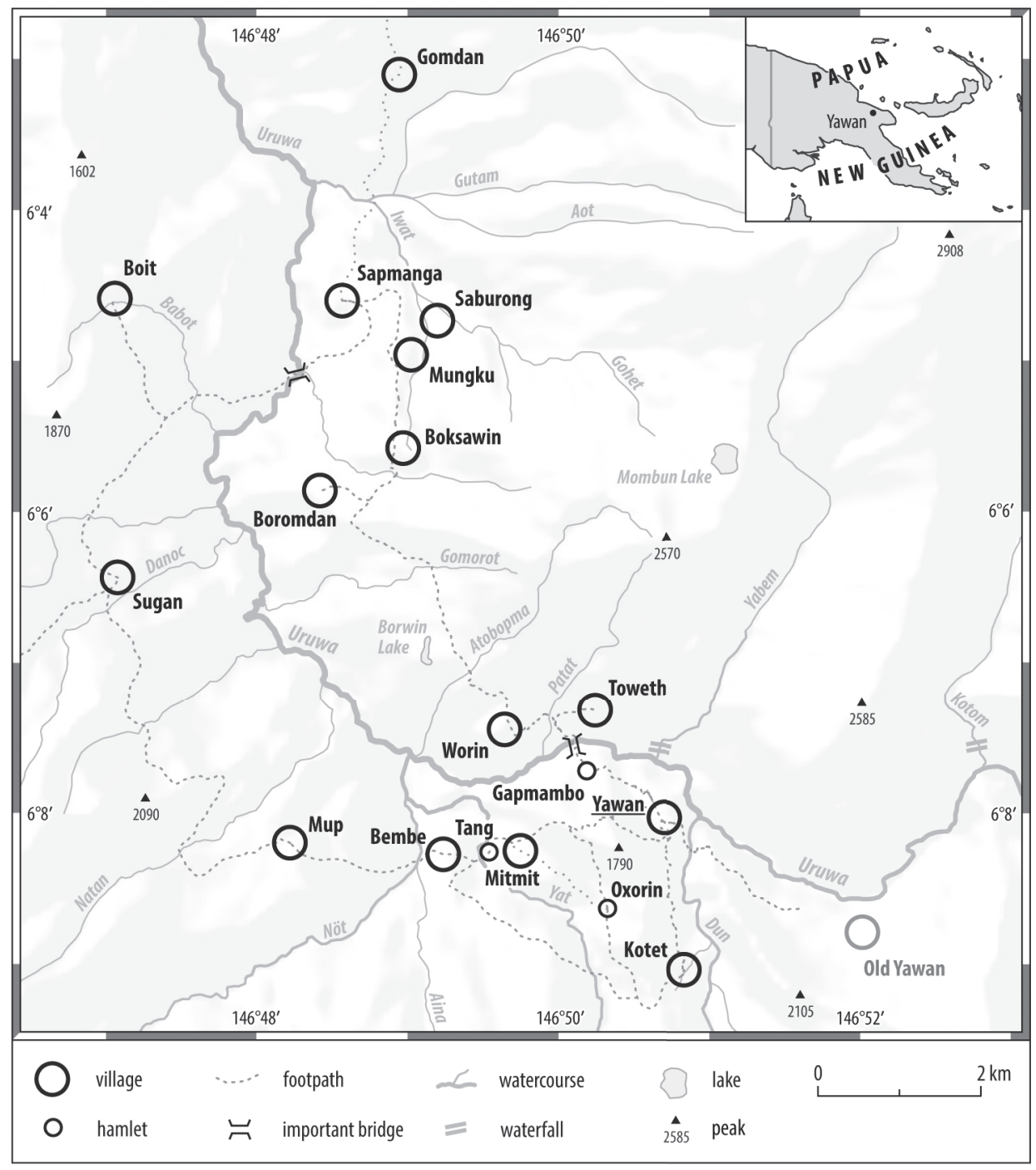

Co Author of the map output: Jan D. Bláha; Software: ArcGIS for Desktop10.4, Adobe Illustrator CS6

Fig. 1 Localization of villages in the Uruwa Valley. Source: authors

The second major event relates to Christian denominations in the area. The entry in the Village Register provides information about a conflict between the Lutheran missionary and the locals; the entry documents that the missionary beat the inhabitants and forced them to work in his gardens. The local people confirmed the same story to the researchers. The researchers were told that the missionary had to leave the community due to this event. The locals were left without Christian services for approximately twenty-five years. An Adventist missionary came to the area at the beginning of the 1970s and many locals 
converted to the new denomination. A Lutheran missionary came back in the mid-seventies and claimed the area for the Lutheran Church. That started a conflict inside the community which is still unresolved. Although one of the researchers witnessed a reconciliation ceremony in 2009, there is still latent tension between people (for more details about the colonial history of the Nungon community and its effect on the spatial behavior see Soukup - Bláha 2017).

\section{Research methodology}

The objective of the research is (1) to study spatial social patterns (by that we mean the spatial expression of social relations and ties in geographical space) with the results in the form of maps, (2) to collect mental maps of the local primary-school pupils and (3) to observe, or test community members when working with maps. The core of the research contains a combination of perspectives and research methods from cultural anthropology and geography. The principal methodological strategy of our research was to employ fieldwork as the main source of evidence. During the fieldwork the sources of evidence were gathered in close cooperation with the locals as they were familiar with the objective and aim of the research. All of this material was collected during the authors' two stays in 2015 and 2016.

\section{1) Study of spatial social patterns}

The basic principle of studying spatial social patterns is, with the cooperation of the locals, to construct genealogical relationships and ties in the community (fig. 2). An integral part of the data collection is the detailed structured information on each particular person in the community consisting of selected attributes; for example, religious denomination or family membership, in particular their residency in a particular home. There is also the mapping of the geographical space of the villages along with a collection of spatial data on borders and information about the land ownership, land use and types of buildings, land-ownership perception and land attachment. Information on borders, land ownership and the perception of it, land use, land attachment, and the types of buildings is gathered via ethnographic interviews as a standard research method in cultural anthropology, as well as using mental maps based on topographic maps.

An analysis of the archive documents provides a description of the history of the community from the perspective of the colonial authorities. The locals' perspective of historical events is found in the interviews with the elders. The results of the analysis, along with the findings provided by the interviews with the elders, provides a construction of the relevant part of the community's past, especially in relation to both the movement of Yawan's inhabitants to a new area and religious conflict. 


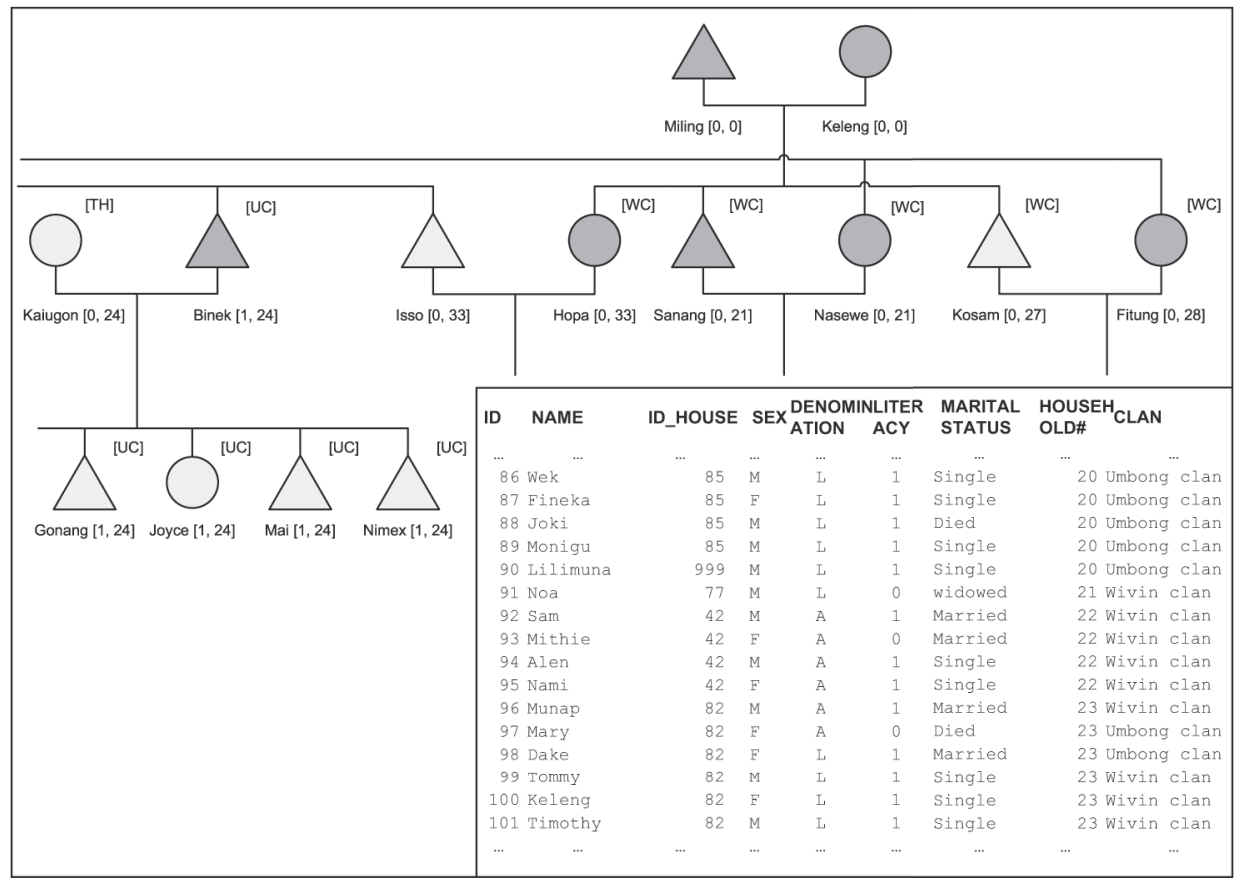

Fig. 2 Examples of genealogical relationships and community ties (May 2015). Source: field research of authors

The principal sources of evidence, i.e. genealogical method and mapping, are standard tools in anthropology and geography, but to combine them is unique in both disciplines. We are fully aware of the critique formulated by Schneider (1968, 1984) and other theorists of kinship. The intention of this research is to model social relationships and community ties as revealed by locals in their views of the genealogical relationships within the community and the way they understand it. We used a standard practice in constructing the genealogical ties in the community (for example, Chagnon 1974; Schusky 1965, but there are many others). The genealogical data are supplemented by residency information (see above) to allow the linking of ethnographic and spatial data.

There are many terrestrial and remote sensing methods which are used to collect spatial (geographical) data. The choice of one particular method is primarily determined by the objective and aim of the study and also by the nature and range of the mapped area. As this particular area of the Uruwa river is located in a part of the world which is only partially mapped, there are no available data of a higher spatial resolution. Moreover, the area is located in an equatorial area which is densely forested, leading to certain technical difficulties. The research focused on the spatial-data collection on the corners of buildings, crossroads, paths, edges, fences, and other landmarks. The buildings were measured with a laser distance meter. The GPS points gathered in 


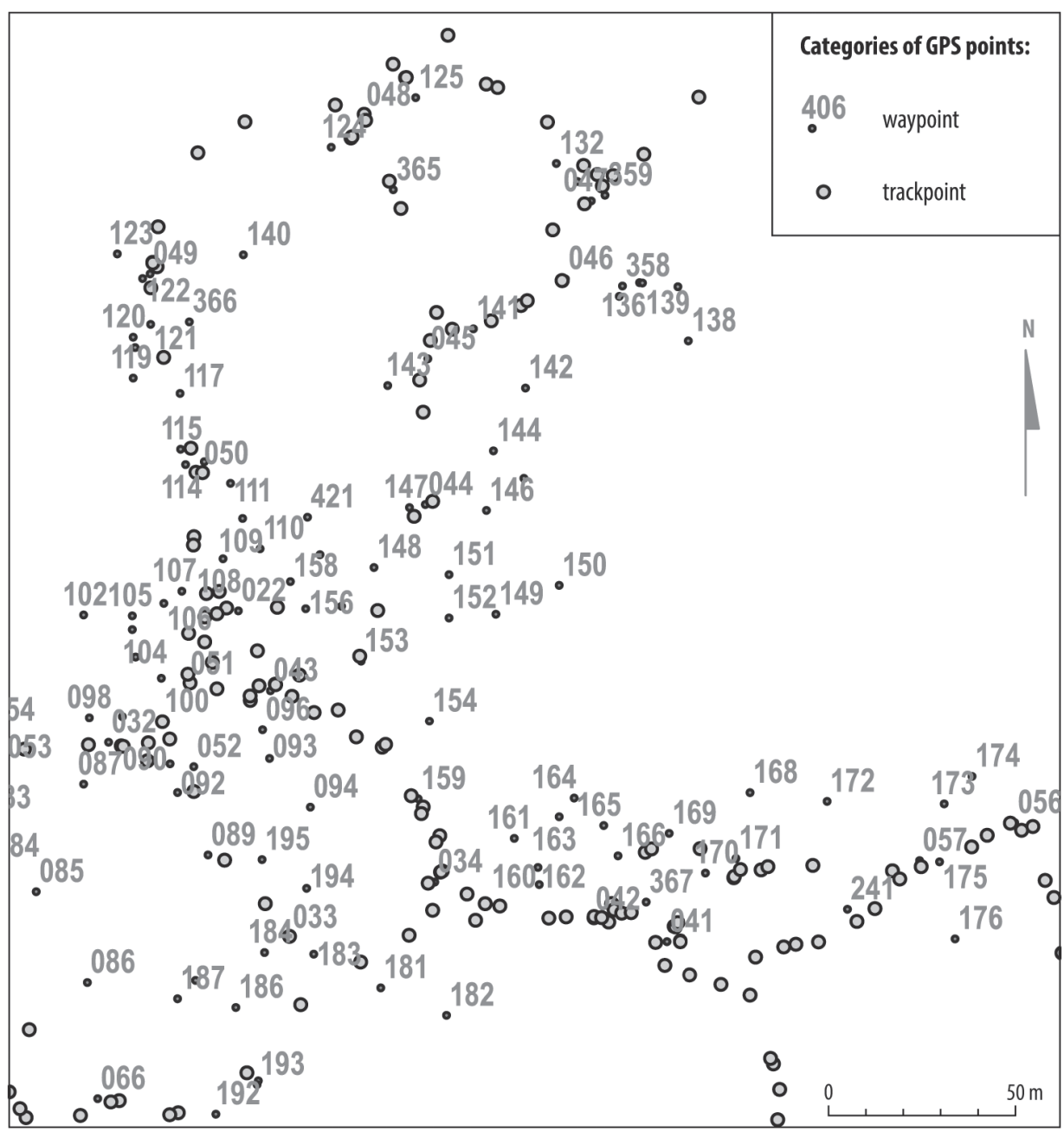

Fig. 3 Example of input spatial GPS data for the village of Yawan (May 2015). Source: authors' field research

the field (fig. 3) will be contextualized using identical points on sketch maps (fig. 4) and aerial photographs.

The authors shared their results of the research, which had been previously carried out in 2015, after their arrival in 2016. Maps of the village (fig. 5) were widely discussed by the community and one of the community leaders started to consider the completed maps as a useful tool for regional planning. At the same time, there was a dilemma for the researchers. For a long time, the community had disagreed on the issue of plots of land dating back to the turn of the 1950s (see Soukup - Bláha 2017). Part of the community requested us to definitively set the boundary between the lands using GPS technology 


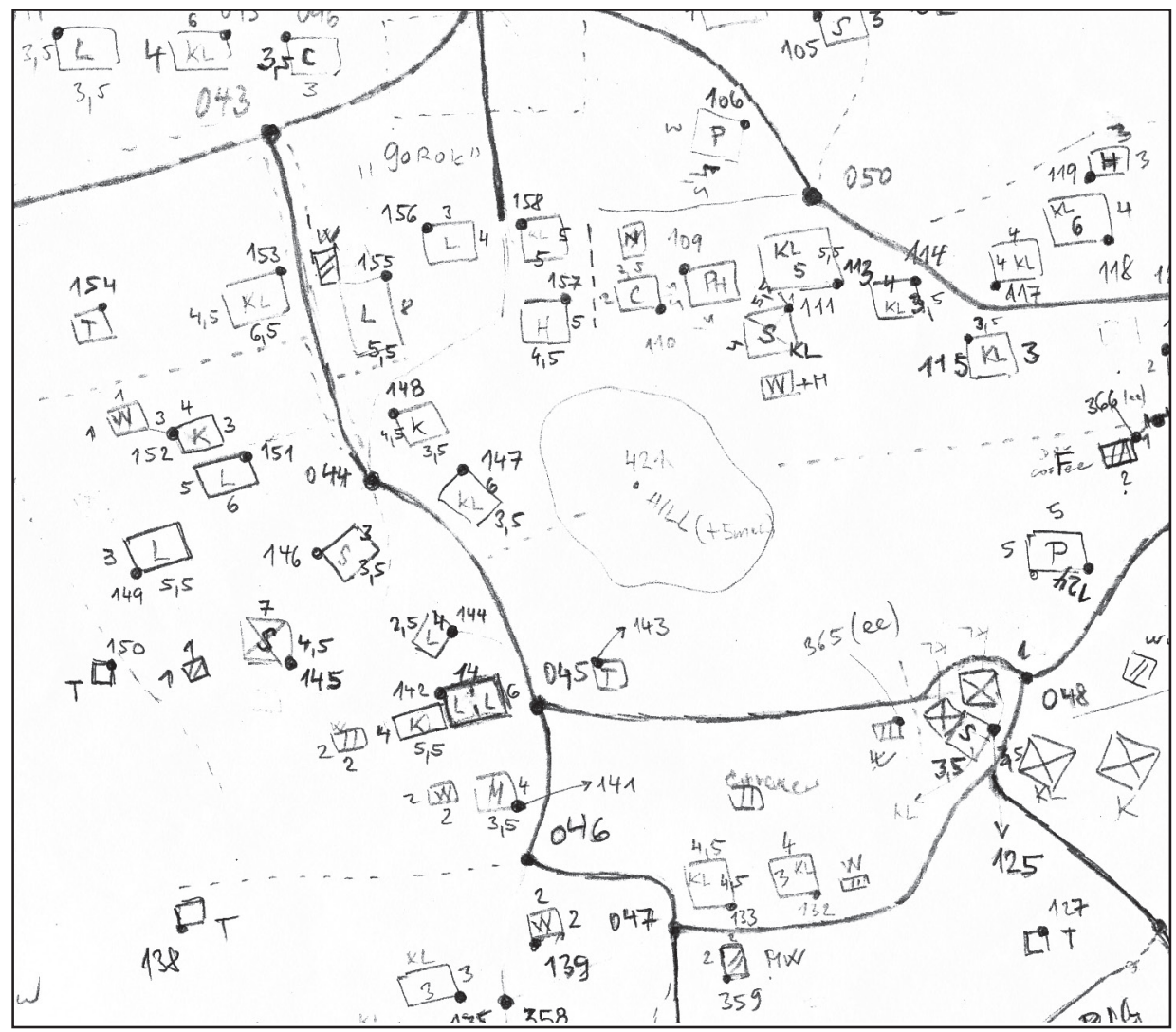

Fig. 4 Example of sketch map of the village of Yawan (May 2015). Source: authors' field research

and thereby help to solve the old issue of land ownership. In this case, the map would have become a powerful tool and would have provided a strong argument in the dispute; however, we declined to participate in this dispute.

\section{2) Mental maps obtained from the community members}

Part of the field research into the Nungon community involved activities connected to obtaining the mental maps of primary-school pupils. Even though it is not a traditional way of using these methods, it is obvious that these maps offer a lot of valuable information about the cultural community and their spatial perception. The research material was obtained directly during lessons at the local school with the help of local teachers, who provided the opportunity to observe pupils and teachers while they were working (see further). When trying to obtain mental maps from adults, we faced a problem with drawing skills and their limitation in participating. Moreover, drawing is a natural activity for children which breaks down barriers and it is also a suitable tool for 


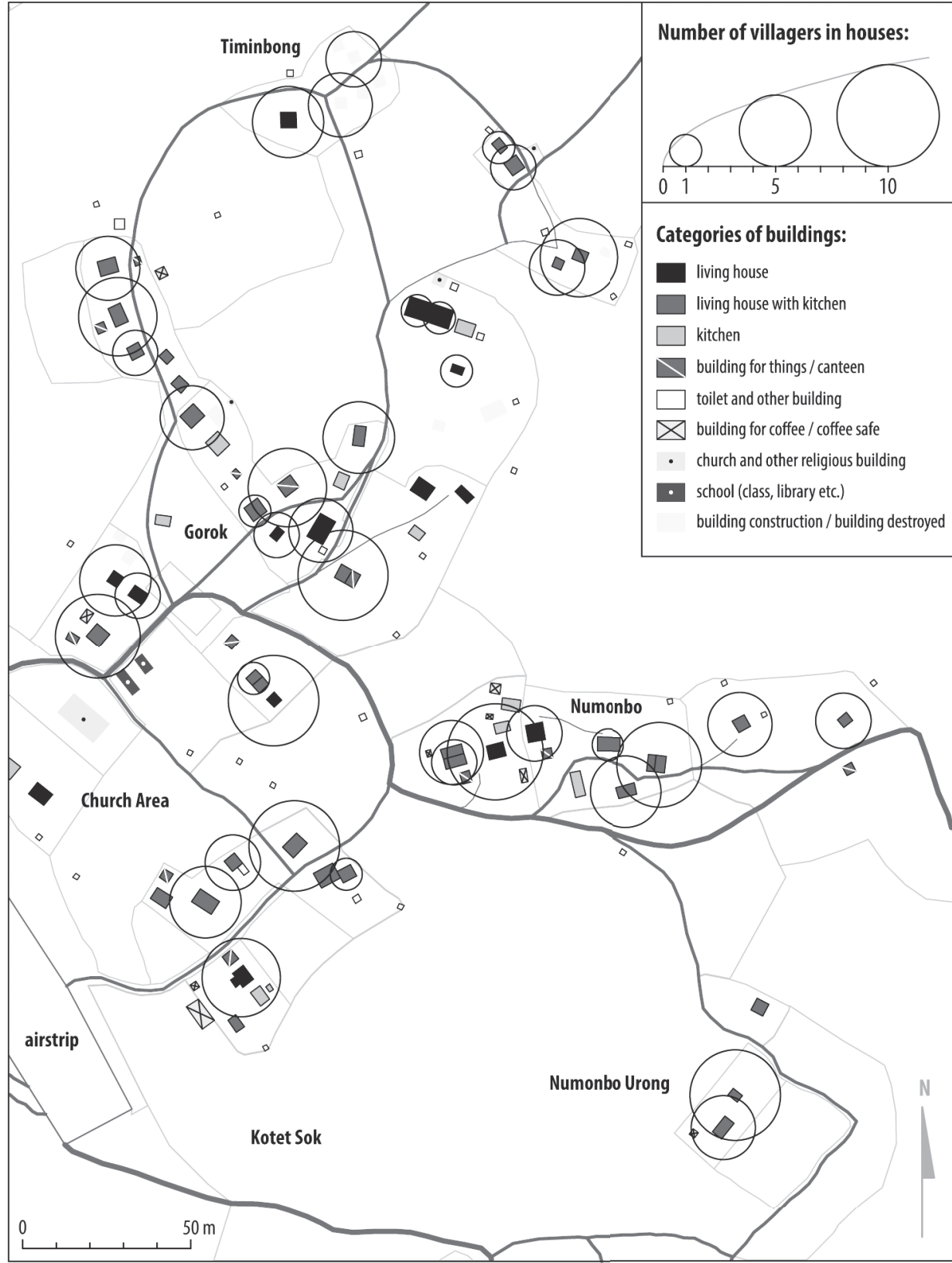

(C) Map base data: authors; author of the map output: Jan D. Bláha; Software: ArcGIS for Desktop10.4, Adobe Illustrator CS6

Fig. 5 The function of the buildings and the number of villagers in the houses of the village of Yawan (May 2015). Source: authors' field research

formulating opinions about this world, although one must allow for its limits, such as the participant’s skills, etc. (Hubeňáková - Soukup 2012). A detailed 
analysis of the Nungon community has been carried out in the past by the authors (Bláha - Soukup - Balcerová 2011; Bláha 2014), and it was based on the previous visits of the community by one of the authors.

During the research in 2015 and 2016 the instructions were clarified and completed for other tasks: (a) to mark a route from home to a familiar or favorite place and mark important places on this route (route), (b) describing the location of home (description of place) and (c) defining the territory of home, boundaries of home (territoriality). Map materials additionally provided mental maps (d) showing differences in the perception of the world map and also knowledge of world geography, as well as (e) emotional mental maps. With maps (d) in particular, one may notice the influence of Western education, maps (e) after aggregation give a view of the community opinion of the living space (see further).

Maps (a) which require charting thematic information (e.g. a certain route) in the contents might be considered cognitively more demanding than a map of the village itself (b) which is a simple expression of spatial perception and living space. Emphasizing the meaning of the thematic content of the map, i.e. to mark the route itself, was apparently passed unnoticed by some pupils. Exceptionally interesting results were produced by maps defining the territory of home (c) often showing a few scales of the pupil's spatial identity with home. Overwhelmingly, the Papuan pupils depict certain areas of the villages of the Nungon community with descriptions and they use colours to differentiate built-up areas from surrounding dense vegetation and gardens. However, some of the maps show a connection of this spatial scheme with a typical outline of the state Papua New Guinea. In an original way, the pupils managed to connect the cultural identity of the Nungon community with the identity of the independent state in which they live.

Following a study by Saarinen $(1988 ; 1999)$ about a different interpretation of the world map by people from different parts of the world, the focus was on mental maps of the world order (d). The aim was to verify whether the influence of the location where one comes from is also shown in the Papuan pupils' mental maps. The resulting maps, where the pupils were asked to put continents into a geographical network made up of the Greenwich meridian and equator, were mainly influenced by the pupils' very poor knowledge of the world order and geography.

One part of the activities relating to spatial anthropology might be mapping spatial emotions in the form of gathering and analyzing emotional mental maps (fig. 6). For this purpose, we used a topographical map of the village of Yawan created in 2015 which used local names and a map legend which had been previously created in cooperation with the community. 


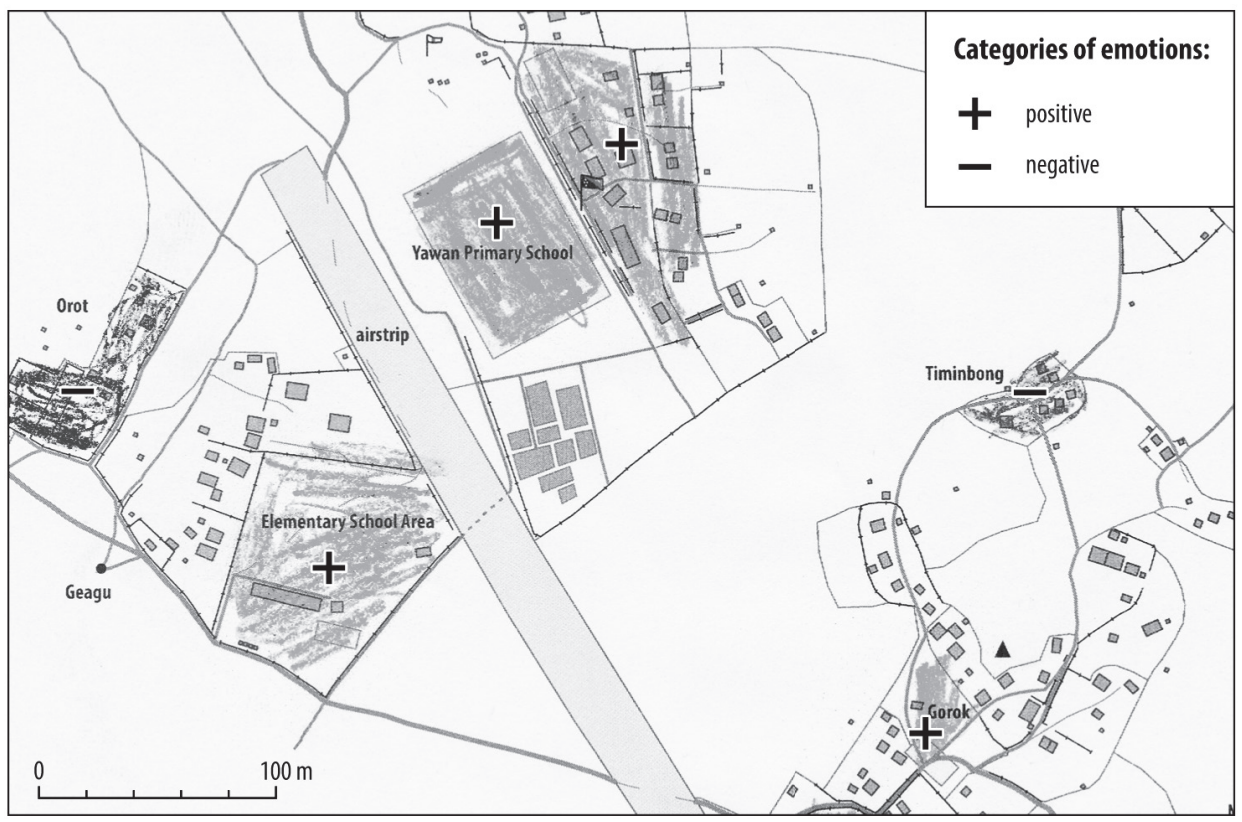

Fig. 6 Example of an emotional mental map (June 2016). Source: authors' field research

\section{3) Observing and testing community members while working with maps}

The field research focusing on studying pupils' mental maps includes features for testing their knowledge and skills. When mental mapping, not only is the participants' spatial perception revealed, but also their orientation in the represented space or other geographic competence. Observing the pupils also shows the way they think about the topic, their cooperation, mutual "copying”, the teacher's efforts to help, and some misconceptions in understanding the instructions by both the pupils and teachers. Since the communication between the teachers and pupils also occurs in Tok Pisin, it is useful to understand its basis to reveal these misconceptions.

When analyzing the mental maps, an important source of information is obtained by documenting all the geography textbooks used. From the research into their visuals (Trahorsch - Bláha - Janko 2018), these textbooks usually come from Australia and contain higher quality visuals including maps. Therefore, the authors believe that the main reasons for misconceptions are: (1) curricula where the emphasis is put on local or national levels due to the time schedule, (2) the importance of the teacher and their preferences, (3) the pupil's class.

These mental maps appear to show that through a western style of education the Papuan pupils gradually acquire competences for working with maps, including more demanding cognitive tasks such as creating their own 
map (Hanus - Marada 2014). It is no surprise that the pupils manage less demanding cognitive tasks, such as using the map too. When working with emotional mental maps, the pupils proved that they can navigate in the map quite well (especially according to local names) and have no difficulties identifying basic objects (landmarks) and finding their homes too.

\section{Conclusion or using the results in the local community}

Obviously, all of the activities mentioned above which were carried out during the field research in 2015 and 2016 show that spatial anthropology, including its various forms and methods, might play an important reciprocal role in communication with the local community. Mapping cultural phenomena on a local scale partly brings new knowledge about the community, and partly a completely new context of information that has already been acquired through the interconnection of different datasets (genealogical and spatial data). Therefore, it is the authors' intention to create software solutions to combine the geographical and ethnographical sources of evidence for the purposes of other research.

Furthermore, the research has shown how valuable detailed topographic maps of a certain territory might be for the community itself. The teachers from the local school and the leader started using maps spontaneously for lessons and other activities. In this regard, maps proved to be an important, powerful tool (Monmonier 1996). The Papuan pupils' emotional maps provide evidence of the spatial universality of emotions and also of the adaptive role of spatial navigation, where one can see the clear influence of education using western teaching aids such as visuals.

The study follows up spatial turn in anthropology. The discipline has been closely connected with geography since its beginnings. One of the "fathers" of anthropology, Franz Boas, developed the spatially informed approach to the study of culture. The approach is labeled difussionism, which has also had its variants in Britain, Austria and Germany. Diffusionists are very often neglected as old-fashioned theorists, but in a globalizing world, they now appear to be more modern than previously thought. To fully understand the spatial aspect of social and cultural phenomena means following them on different levels - local, regional, macro-regional and global and their mutual interconnections. Therefore, if we were to define our own position, we would call it neo-diffusionism, but this will be a matter for discussion in a separate study.

August 2018 


\section{References}

Appadurai, Arjun. 1996. Modernity At Large. Minneapolis: University of Minnesota Press. Barnard, Alan. 2000. History and theory in anthropology. Cambridge: Cambridge University Press.

Benedek, András - Nyíri, Kristóf (eds.). 2012. The iconic turn in education. Frankfurt am Main: Peter Lang.

Bláha, Jan D. - Soukup, Martin - Balcerová, Michaela. 2011. Mentální mapy obyvatel vesnice Yawan v interdisciplinární perspektivě. Kartografické listy 19: 5-19.

Bláha, Jan D. 2014. Geneze kulturní diverzity a kulturní unifikace mapových stylů. Culturologia: Journal of Culture 3 (2): 57-60.

Bodenhamer, David - Corrigan, John - Harris, Trevor. 2010. Spatial Humanities. Bloomington: Indiana University Press.

Bourdieu, Pierre. 2002. Masculine Dominantion. Stanford: Stanford University Press.

Carrier, James (ed.). 1990. History and tradition in Melanesian anthropology. Berkeley: University of California Press.

Clifford, Nicholas J. - Holloway, Sarah L. - Rice, Stephen P. - Valentine, Gill (eds.). 2009. Key concepts in geography. Los Angeles: Sage.

Crang, Mike. 1998. Cultural geography. London: Routledge.

Dikovitskaya, Margarita. 2005. Visual culture: The study of the visual after the cultural turn. Cambridge: MIT Press.

Dodge, Martin - Kitchin, Rob - Perkins, Chris. 2009. The map reader. Chichester: Wiley.

Dostal, Walter. 1984. Toward Ethnographic Cartography: A Case Study. Current Anthropology 25 (3): 340-344.

Downs, Roger M. - Stea, David (eds.). 1973. Image and environment: cognitive mapping and spatial behavior. Chicago: Aldine.

Durranti, Alessandro. 1992. Language and Bodies in Social Space: Samoan Ceremonial Greetings. American Anthropologist 94 (3): 657-691.

Evans-Pritchard, Edward. 1951. Kinship and marriage among the Nuer. Oxford: Clarendon Press.

Fabian, Johannes. 1983. Time and the other. New York: Columbia University Press.

Gammage, Bill. 1998. The sky travelers. Calton: Melbourne University Press.

Hanus, Martin - Marada, Miroslav. 2014. Mapové dovednosti: vymezení a výzkum. Geografie 119 (4): 406-422.

Hubeňáková, Júlie - Soukup, Martin. 2012. Nungon People of Uruwa. Červený Kostelec: Pavel Mervart.

Chagnon, Napoleon. 1974. Studying Yanomamo. New York: Holt, Rinehart and Winston.

Chapin, Mac - Lamb, Zachary - Threlkeld, Bill. 2005. Mapping indigenous lands. Annual Review of Anthropology 34 (1): 619-638.

Kress, Gunther - van Leeuwen, Theo. 1990. Reading images. The Grammar of Visual Design. Victoria: Deakin University.

Kuper, Adam. 2006. Anthropology and anthropologists. London: Routledge.

LaSpina, James A. 1998. The visual turn and the transformation of the textbook. New York, London: Routledge.

Leach, Edmund. 1961. Pul Eliya, A Village in Ceylon: A Study of Land

Tenure and Kinship. Cambridge: Cambridge University Press.

Low, Setha (ed.). 2003. The Anthropology of Space and Place. London: Blackwell.

Low, Setha. 2016. Spatializing Culture. London: Routledge.

Marcus, George. 1995. Ethnography in/of the World System: The Emergence of Multi-Sited Ethnography. Annual Review of Anthropology 24: 95-117.

Mayer, Richard E. 2001. Multimedia learning. Cambridge : Cambridge University Press. 
Monmonier, Mark. 1996. How To Lie With Maps. Chicago: University of Chicago.

Murdock, George. 1967. Ethnographic Atlas. Pittsburgh: University of Pittsburgh Press.

Okénková, Věra. 2015. Využití konceptů míst v antropologii a př́buzných vědách. Lidé města 17 (3): 513-528.

Pichón, Francisco. 1996. The forest conversion process: a discussion of the sustainability of predominant land uses associated with frontier expansion in the Amazon. Agriculture and Human Values 13: 32-51.

Pospisil, Leopold. 1995. Obernberg. New Haven: Connecticut Academy of Arts and Sciences.

Price, David. 2004. Atlas of World Cultures. Caldwell: The Blackburn Press.

Rabinow, Paul - Marcus, George - Faubion, James - Rees, Tobias. 2008. Designs for an anthropology of the contemporary. Durham: Duke University Press.

Ringshausen, Gerhard. 1976. Von der Buchillustration zum Unterrichtsmedium. Weinhem: Beltz Verlag.

Roberts, Les (ed.). 2012. Mapping cultures. New York: Palgrave Macmillan.

Roberts, Les. 2018. Spatial Anthropology: Excursions in Liminal

Space. London: Rowman \& Littlefield International.

Rosaldo, Renato. 1980. Ilongot Headhunting, 1883-1974. Stanford: Stanford University Press.

Řezníčková, Dana. 2015. Didaktika geografie: proměny identity oboru.

In: Stuchlíková, I. - Janík, T. (eds.): Oborové didaktiky: vývoj - stav - perspektivy. Brno: Masarykova univerzita: 259-288.

Saarinen, Thomas F. 1988. Centering of Mental Maps of the World. National Geographic Research 4 (1): 112-127.

Saarinen, Thomas F. 1999. The Eurocentric Nature of Mental Maps of the World. Research in Geographic Education 1 (2): 136-178.

Sauer, Carl O. 1925. The Morphology of Landscape. Berkeley: University of California Press.

Schieffelin, Edward - Crittenden, Robert (eds.). 1991. Like people you see in a dream. Stanford: Stanford University Press.

Schneider, David. 1968. American kinship. Englewood Cliffs, N. J.: Prentice-Hall.

Schneider, David. 1984. A critique of the study of kinship.

Ann Arbor: University of Michigan Press.

Schusky, Ernest. 1965. Manual for kinship analysis. New York: Holt, Rinehart and Winston.

Soukup, Martin. 2011. A Visualization and Representation of the Culture in Yawan, Papua New Guinea: Drawings in the Context of a Visual Anthropology. Anthropologia integra 2 (2): 41-51.

Soukup, Martin - Bláha, Jan D. 2017. Koloniální minulost etnické skupiny Nungon a její dopad na prostorové chování lidí. Historická sociologie: časopis pro historické sociální vědy (1): 55-72.

Stocking, George W. 1995. After Tylor. Madison: University of Wisconsin Press.

Trahorsch, Petr - Bláha, Jan D. - Janko, Tomáš. 2018. Analýza výzkumů vizuálií v učebnicích na příkladu učebnic s geografickým obsahem. Pedagogická orientace 28 (1): 111-134.

Tuan, Yi-Fu. 1977. Space and Place: The Perspective of Experience. Minneapolis: University of Minnesota Press.

Village Register. 1940. Port Moresby: Territory of Papua and New Guinea.

Wegmann, Urs. 1990. Yau Anthropology Background Study. S.I.: SIL Papua New Guinea.

Zedeño, María. 1997. Landscapes, land use and the history of territory formation: An example from Puebloan Southwest. Journal of Archaeological Method and Theory 4 (1): 67-102. 